\title{
Using ICT Devices in the Urban Public Spaces of Colombo: Virtual Socializing and Social Distancing During the Covid-19 Pandemic
}

\author{
Kavisha Charukshi de Silva, Ajitha llangaratne, \\ Jeewanthi Senadheera \\ City School of Architecture, Colombo, Sri Lanka.
}

Corresponding Author: Kavisha Charukshi de Silva kavishacharukshi@gmail.com

\begin{abstract}
Urban public spaces form an integral part of city life and its built environment, facilitating space for formal and informal social gatherings, relaxation and entertainment. In this digital era, the traditional use of public space as a place of social gathering has been gradually modified due to the development of portable Information \& Communication Technology (ICT) devices. Its ability to retain constant connection via digital media has resulted in the creation of virtual public spaces. On the other hand, the outbreak of Covid 19 pandemic has changed the initial use of urban public spaces due to physical distancing and other strict guidelines, and has compromised many public interactions we were accustomed to.

This study aims to explore the shift in social behaviour and formation of private realms due to the usage of portable ICT devices in public spaces and the physical elements which facilitate these shifts. Further it aims to understand design considerations that could be used to facilitate social distancing practices. In exploring the research question, an ethnographical method has been adopted. The chosen urban public spaces were studied through observational survey, activity mapping, photographic survey, and field interviews.

The findings show a distinctive intervention of these devices with social behaviour in public spaces. It shows the importance of addressing the urban public space in terms of these marked shifts based on its typology and functional characteristics.

Further, some of the above findings throw light on the future prospects of urban public spaces which are currently in limbo due to social distancing practices. This paper suggests that ICT devices can become a useful tool in maintaining an active public interaction and social inclusion in countering the adversities on society brought upon by drastic preventive regulatory actions in the face of an unprecedented event as experienced presently.
\end{abstract}

Keywords: Socio-spatial practices, portable ICT devices, personal territories, social distancing, urban public spaces. 


\section{Introduction}

Public spaces have played a significant role in fostering social activities and creating a platform for human movement, communication, enjoyment and relaxation (Gehl \& Svarre, 2013; Stadler, 2013). An extensive number of research on urban public spaces vouchsafe that architects and urban planners could play a prominent role in shaping the urban form and providing spaces that facilitate these social activities. In the modern day, due to the development of portable ICT (Information \& Communication Technology) devices and ubiquitous internet access, public spaces have extended beyond the physical boundaries to the virtual space, allowing public activities to occur in a multi-dimensional public sphere (Hampton et al., 2010; Abdel-Aziz, AbdelSalam and El-Sayad, 2016) .

Duffey (2014) argues that ICT has filtered into the urban form reshaping social interaction. However, the need of physical public spaces and social interactions remain consistent while the altered digital framework continue to influence the social activities. Therefore, it is important to have a comprehensive understanding on how the emerging ICT device users adapt and modify the norms of public spaces and outdoor activities.

On a different note, due to the sudden outbreak of Covid 19 pandemic, health and safety measures have suddenly restricted the much desired social activities \& interactions in public spaces. Physical distancing in preventing the spread of virus has ever changed the use and definition of the public interactive spaces. During the time of lockdown social interactions were limited to virtual means of communication via ICT devices revealing the magnitude of its mediation on the contemporary lifestyle.

Ongoing debates have been brought forth the need of understanding the evolving relationship between people, ICT and public spaces. Globally, scholars have begun to explore theoretical concepts on creating digitally mediated public spaces (Smaniotto Costa et al., 2019) and integrating ICT intervention to enable social distancing in public spaces (Nguyen et al., 2020). However, it is still uncertain what would be the full impact of COVID-19 on future public space and its definition. In a time where there is a gap in the Sri Lankan knowledge database on this particular subject matter, this study would aid to understand the contemporary spatial appropriation of the emerging ICT device users in urban public spaces while initiating a discourse of its' mediation in social distancing in public spaces.

\section{Theoretical Framework \\ Urban Public Spaces \& Social Behaviour}

Almatarneh (2014) sates that the public sphere is the platform that hosts different functions by providing meeting spaces, defining spaces for local traditions and identifying meaning and identity studying Activity Patterns and Design Features Relationships in Urban Public Spaces. Public spaces provide the opportunity for anticipated encounters with existing acquaintances and serendipitous encounters with strangers (Sennett,1977;Hampton, Goulet and Albanesius, 2015). Howell (1993) and Fritz (2013) further claim that ICT does not limit the public sphere to the physical setting but extends beyond the physical boundaries to the virtual space.

Public spaces, which are part of the public sphere that includes streets, sidewalks, parks, and plazas, is identified by Sennett (1977), as a socio-spatial territory that promotes and manages interpersonal relationships. According to Goffman (1963) these spaces allow individuals to follow patterns of beliefs and behaviour while creating a psychological connection to the space. Therefore public spaces fulfil the need of people by providing a platform for commercial, political and communal activities.

The built environment has the ability to influence social activities and encourage encounters among acquaintances and strangers. It only provides the spatial setting for these social activities to occur but cannot influence the quality, content, and intensity of these encounters 
(Carmona et al. ,2010; Gehl, 2011; Rasouli, 2013). The spatial patterns are constrained by environmental opportunities provided for them and can depend on social, cultural and perceptual context (Carmona et al., 2010).

Sociologist, Erving Goffman (1963) claims that social situations vary, and individuals' reactions depend on the degree of the individual's obligation to the physical and the social context in which he is embedded.

The spatial and social practices are also a result of the social structure and spatial stimulations, meaning the design, the equipment and facilities available, and the management affect how people use the space and behave in that space (Menezes and Smaniotto Costa, 2017). Jan Ghel (2011) and William Whyte (1980) state that the use of public spaces is an empirical result of the physical qualities of space. There is a close relationship between the quality of urban space and people's behaviour. Gehl (2011) explicates that better the quality of spaces, higher the frequency of optional and social activities. The quality of space creates a positive or negative condition to stay outdoors. When the quality of space is better, people spend more time in the outdoors. This increases frequency of optional and social activities. (Maksymiuket al., 2017). William H. Whyte (1980) also identifies that people attract other people to public spaces. People being present in public space encourages more social encounters (Gehl, 2011). Therefore Whyte (1980) argues that public spaces should be designed to encourage people to linger. Staying in a place involve peoples' engagement with the space.

Two major types of engagement with the space is outlined by Carmona et al. (2010) :

Passive engagement: these engagements occur when appropriated physical surrounding provides a sense of relaxation, where active involvement is not necessary. Sitting and watching people are forms of passive engagements (Carmona et al., 2010) which often occur next to the pedestrian flow where physical setting provides seating choices.

Active engagement: This relates to active experiences resulting in social interaction among people, who are physically present in that space. Different levels of active engagement can be observed at public spaces. Designed elements such as street furniture, sculptures, street art, fitness and children's play units and water features encourage both active and passive engagement even among strangers (Carmona et al., 2010).

In addition, Gehl (2011) categorizes social interactions into three human activities: seeing, hearing (passive engagement) and talking (active engagement). He states that the success of the outdoor public spaces depends on nature of the activities that take place and identifies three types of outdoor activities.

1. Necessary activities: essential tasks which do not depend on the quality of space

2. Optional activities: recreational activities which are highly dependent on the quality of space 3 . Social activities: resultant activities of the above which depend on the presence of people and quality of space.

People are a key factor in creating active public spaces in which two types of people are present ; 'Singles' and 'Withs' (Goffman, 1971). Singles lingering in public spaces are much more prone to vulnerable passive engagement than Withs.

However, contradictory augments have being presented by scholars Humphreys (2005), Hampton et al. (2010) Hatuka and Toch (2016); Lehel (2016) on influence of portable ICT devices 
and individuals' engagement with the immediate surrounding in the era of digitalization which are summarized henceforth.

\section{Public Spaces and Social Behaviour in the Era of Digitalization}

Social media and digital technologies have become an essential part of everyday life of urbanites. As technology develops in a rapid race the lifestyles of the contemporary man alters to adapt to this change (Abdel-Aziz, Abdel-Salam and El-Sayad, 2016).

Studies indicate that people are more isolated and removed from spaces than in the past. Scholars argue that media technologies have resulted in resembling public space as more of a 'spaces of flow' than space for social gathering (Turkle, 2011; Maksymiuk et al., 2017). ICT has created a whole new social landscape that is identified as the virtual public space (Humphreys, 2005). Virtual public spaces generates virtual environments for people to communicate while allowing multiple individuals be omnipresence in the same realm. It generates a virtual environment populated by virtual communities (Lehel, 2016).

\section{Impact of ICT Artifacts on Public Space and Social Behaviour}

Hampton, Goulet and Albanesius,( 2015); Hatuka and Toch (2016) argue portable ICT devices are redefining the relationships between physical, virtual, and social dynamics in public spaces. ICT devices such as smartphones, laptops and tablets allows individuals to engage simultaneously in multiple spheres while physically being present in the public space (Duffey, 2014; Hatuka and Toch, 2016; Lehel, 2016). This psychologically detaches the user from the physical surrounding and increases inattention to the surrounding environment. (Hatuka and Toch, 2016; Lehel, 2016). Due to this, social territories are gradually mediated, reducing the "person-to-place and person-to-person connections" in physical public space. (Hatuka and Toch, 2016).

On the contrary, Sociologists Hampton, Goulet and Albanesius, (2015) argues that when ICT device use is treated as a communication tool, it expands social interactions beyond physical boundaries. Additionally they states portable ICT device users are more likely to be observed at transitional public spaces that are used for purpose of waiting between destinations. Destination public spaces are identified as spaces where people come exclusively to that spaces and intermediate public spaces are used for both the above purposes. Hampton, Goulet and Albanesius, (2015) Identifies this as the functional characteristics of a public space which is predominantly based on the usage of that space.

ICT device uses have introduced new activities in public spaces which Hatuka and Toch (2016) and Sassen (2015) explicate as creation of portable private - personal territories and engaging in digitally mediated outdoor activities.

\section{Portable Private - Personal Territories (PPPT)}

Hatuka and Toch (2016) state that particularly smartphones contribute in creating a portable private-personal territory (PPPT). "It is a socio - spatial condition that contributes in blurring definition of private and public, in which personal space is expanded to offer the individual the ability to navigate between the material and the immaterial" (Hatuka and Toch, 2016). This dynamic personal space modifies interaction rituals in public (Hampton, Goulet and Albanesius, 2015; Hatuka and Toch, 2016).

\section{Digitally Mediated Outdoor Activities}

Sassen (2015) states that ICT devices acts as interface that digitally mediate necessary, optional and social activities. These devices facilitate virtual optional and social activities. However use of ICT Devices for virtual optional and social activities may not entirely depend on the physical quality of the space they are used in. (Sassen, 2015). 


\section{COVID 19 and Social Behaviour in Public Spaces}

Covid 19 is not the first pandemic which influenced architect and planners to rethink planning and design strategies for the built environment. In the past plague, typhoid, polio, and Spanish flu breakouts encouraged planners, architects and engineers to re-design and improve sanitary conditions, open spaces of cities. (Ghoneim and Megahed, 2020).

During the Covid 19 pandemic the role of the public space clearly changed (Samuelsson et al., 2020).Restrictive measures on the use of public spaces were essential in controlling the transmission of Covid 19 virus and maintaining public health. Countries worldwide imposed "lockdowns" and "physical distancing" limiting the participation of people in public space and thus limiting public life. Nguyen et al., (2020) defines social distancing as a non-pharmaceutical measure to reduce the frequency of physical contacts between people during an infectious disease outbreak.

During the peak of the spread of Covid-19 and post lockdown, restrictions imposed regarding social interaction challenged the role of the public space (Ghoneim and Megahed, 2020). Though uncertain, many scholars predict that adhering to these new social norm will limit the possibility of spontaneous and informal interaction especially among strangers (Samuelsson et al., 2020).Digital space became prominent as a platform for sharing information and enabling human interaction (Ghoneim and Megahed, 2020) encouraging scholars to explore methods of integrating digital layers for safer public spaces (Nguyen et al., 2020).

Ongoing global research has already identified modifications in outdoor activities due to portable ICT devices and now Covid 19 has further changes these modifications, raising many uncertainties about design and use of future public spaces (Ghoneim and Megahed, 2020).

This research identifies modifications in socio - spatial practice due to portable ICT devices, by carefully understanding, observing and analysing established social behaviour practices and physical characteristics of outdoor public spaces which stimulate these behaviour patterns. Whtye (1980), Cooper Marcus and Francis (1997) and Gehl (2011) identify physical features that stimulate social behaviour and Hampton (2015) outlines characteristics in the usage of outdoor public spaces which determines these behavioural practices.

For the purpose of this study following attributes were derived based on their findings.

Table 1: Attributes of Simulative Spatial Characteristics of Outdoor Public Spaces

\begin{tabular}{|l|l|l|}
\hline \multicolumn{2}{|l|}{ Seating } \\
\hline \multirow{2}{*}{$\begin{array}{l}\text { Types of } \\
\text { Seating }\end{array}$} & Ledges & $\begin{array}{l}\text { Comfortable height and depth encourage sitting activities. There is less } \\
\text { possibility to cluster and engage in face to face interactions. }\end{array}$ \\
\cline { 2 - 4 } & Steps & $\begin{array}{l}\text { Allow more seating space. Give more flexibility for clustering and face to face } \\
\text { interactions. }\end{array}$ \\
\cline { 2 - 4 } & Benches & $\begin{array}{l}\text { In most cases benches are fixed to a permanent location, isolated and do not } \\
\text { promote clustering but placed in a niche, offers intimacy and security for } \\
\text { individuals to stay. }\end{array}$ \\
\cline { 2 - 4 } $\begin{array}{l}\text { Chairs } \\
\text { Seating }\end{array}$ & $\begin{array}{l}\text { Chairs can be categorized as movable and fixed. Movable chairs - infinite } \\
\text { possibilities of clustering and ensures social comfortability. Fixed chairs - only } \\
\text { one option. When occupied by an individual, it is socially uncomfortable for } \\
\text { another to occupy a same bench and thus increase isolation in a public space. }\end{array}$ \\
\hline \hline
\end{tabular}




\begin{tabular}{|c|c|c|}
\hline Orientation & \multicolumn{2}{|c|}{$\begin{array}{l}\text { Orientation of seating stimulates passive or active engagement with the surrounding social } \\
\text { and physical context. }\end{array}$} \\
\hline Clustering & \multicolumn{2}{|c|}{$\begin{array}{l}\text { Availability and flexibility in clustering allow social comfortability and encourage social } \\
\text { interactions. }\end{array}$} \\
\hline \multicolumn{3}{|c|}{ Natural Elements } \\
\hline Sun/ Shade & $\begin{array}{l}\text { Due to the tropical humid climate people prefer shading than being } \\
\text { exposed to the sun (Johansson and Emmanuel, 2006). }\end{array}$ & \multirow{3}{*}{$\begin{array}{l}\text { These elements } \\
\text { encourage people to } \\
\text { linger, interact and } \\
\text { facilitate active and } \\
\text { passive engagement } \\
\text { with surrounding } \\
\text { social and physical } \\
\text { context. }\end{array}$} \\
\hline Trees & $\begin{array}{l}\text { It provides comfortable micro- climates through shading and sense } \\
\text { of enclosure. (Whyte, 1980) }\end{array}$ & \\
\hline Water & $\begin{array}{l}\text { Having the possibility to hear, see and feel water attracts people to } \\
\text { public spaces. Existence of water makes public spaces more } \\
\text { attractive and encourages both optional and social activities (Whyte, } \\
\text { 1980) }\end{array}$ & \\
\hline
\end{tabular}

Table 2: Attributes of Socio - Spatial Practices in Outdoor Public Spaces

\begin{tabular}{|c|c|c|}
\hline \multicolumn{3}{|c|}{ Stationary Activities } \\
\hline Sitting & $\begin{array}{l}\text { Climatic and physical conditions of the environment } \\
\text { influence sitting activities. The location, orientation and } \\
\text { the type of seats determine sitting activities (Whyte, 1980; } \\
\text { Gehl, 2011) }\end{array}$ & \multirow{2}{*}{$\begin{array}{l}\text { Stationary activities } \\
\text { encourage lingering and } \\
\text { prolonged stays in public } \\
\text { spaces. Quality of the } \\
\text { outdoor space has an } \\
\text { influence on these } \\
\text { stationery activities. }\end{array}$} \\
\hline Standing & $\begin{array}{l}\text { Prolonged stay may be due to a purpose. Standing } \\
\text { requires comfortable physical and social environments. } \\
\text { (Whyte, 1980; Gehl, 2011) }\end{array}$ & \\
\hline \multicolumn{3}{|c|}{ Behavioural Practices } \\
\hline Edge Effect & $\begin{array}{l}\text { People position themselves away from the natural } \\
\text { pedestrian flow and locate themselves at the edges of } \\
\text { space. This phenomena increases stationary activities } \\
\text { and passive interactions (Gehl, 2011) }\end{array}$ & \multirow{6}{*}{$\begin{array}{l}\text { These behavioural } \\
\text { practices encourage social } \\
\text { interactions and facilitate } \\
\text { active and passive } \\
\text { engagement with } \\
\text { surrounding social and } \\
\text { physical context. }\end{array}$} \\
\hline Water Effect & $\begin{array}{l}\text { The desirable sound of the water attracts people } \\
\text { towards water feature and has a calming effect on people } \\
\text { (Whyte, 1980). }\end{array}$ & \\
\hline Piano Effect & $\begin{array}{l}\text { People position themselves along walls close to a } \\
\text { supporting furniture or a column, such as a piano (Gehl, } \\
\text { 2011). Encourages people to linger. }\end{array}$ & \\
\hline Niche Effect & $\begin{array}{l}\text { People position themselves in niches for comfortable stay. } \\
\text { This phenomena increases stationary activities and } \\
\text { passive interactions (Gehl, 2011). }\end{array}$ & \\
\hline Tree Effect & $\begin{array}{l}\text { Trees function as enclosures providing comfortable } \\
\text { micro climates. They encourage and prolong stays in } \\
\text { public spaces. }\end{array}$ & \\
\hline Triangulation & $\begin{array}{l}\text { Takes place when an external stimulus arouses common } \\
\text { interest with strangers, encouraging possibilities of social } \\
\text { interactions. }\end{array}$ & \\
\hline
\end{tabular}




\section{Method of Study - Ethnographical Research Method}

Ethnographical research method used in this study is adapted from Smaniotto Costa et al. ( 2019)'s Cyber Parks Project research which explores the relationship between people, spaces and technology. This method allows the researcher to study the user's behaviour patterns in its natural environments.

The data collection method is based on the recommendations outlined in the book How to Study Public Life by Jan Gehl et al, in 2013. The primary data in the study were gathered through direct observations. Sight is considered a central tool in public life studies, yet other senses must also be used to accurately emulate the real-world conditions. (Carter, 197; Gehl and Svarre, 2013). Therefore observations and documentation was manually conducted by the author with the aid of behaviour maps, diary notes and photographs to get an in-depth understanding of observations. The study was conducted as a "one -way interaction observation". This enabled the possibility of observing the urbanites in their natural behaviour with minimum disturbances (Gehl and Svarre, 2013). Observations were conducted at each site during two days of the week (a weekday and a weekend) and documented within three time slots identified with the aid of a pilot study. Semi structured contextual interviews were carried out on random sampling technique to understand the background to the following observed activities which were identified through the pilot observations.

\begin{tabular}{|l|l|l|l|}
\hline $\begin{array}{l}\text { PPPT BASED } \\
\text { ACTIVITIES }\end{array}$ & $\begin{array}{l}\text { DIGITALIY } \\
\text { MEDIATED } \\
\text { ACTIVITIES }\end{array}$ & $\begin{array}{l}\text { Conventional } \\
\text { activities }\end{array}$ & $\begin{array}{l}\text { Conventional + PPPT } \\
\text { based activities }\end{array}$ \\
\cline { 2 - 4 } & (Dual attention) \\
\hline $\begin{array}{l}\text { Talking on the } \\
\text { smartphone } \\
\text { smazing at the } \\
\begin{array}{l}\text { Sitting and gazing at } \\
\text { the phone }\end{array}\end{array}$ & $\begin{array}{l}\text { Taking selfies } \\
\text { Taking photos } \\
\text { Working on ICT } \\
\text { devices (laptops) } \\
\text { Video chatting } \\
\text { Using Video sharing } \\
\text { social networking } \\
\text { apps }\end{array}$ & $\begin{array}{l}\text { Sitting } \\
\text { Standing } \\
\text { Working }\end{array}$ & $\begin{array}{l}\text { Sitting and gazing at } \\
\text { the phone ( while } \\
\text { observing their } \\
\text { children play) }\end{array}$ \\
\hline
\end{tabular}

Fig. 1: Outdoor activities observed at selected case studies Source: author

In analysing the collected data, systematic analysis and tabulation of data against the 5 link points established by Smaniotto Costa et al. (2019) was adopted. 


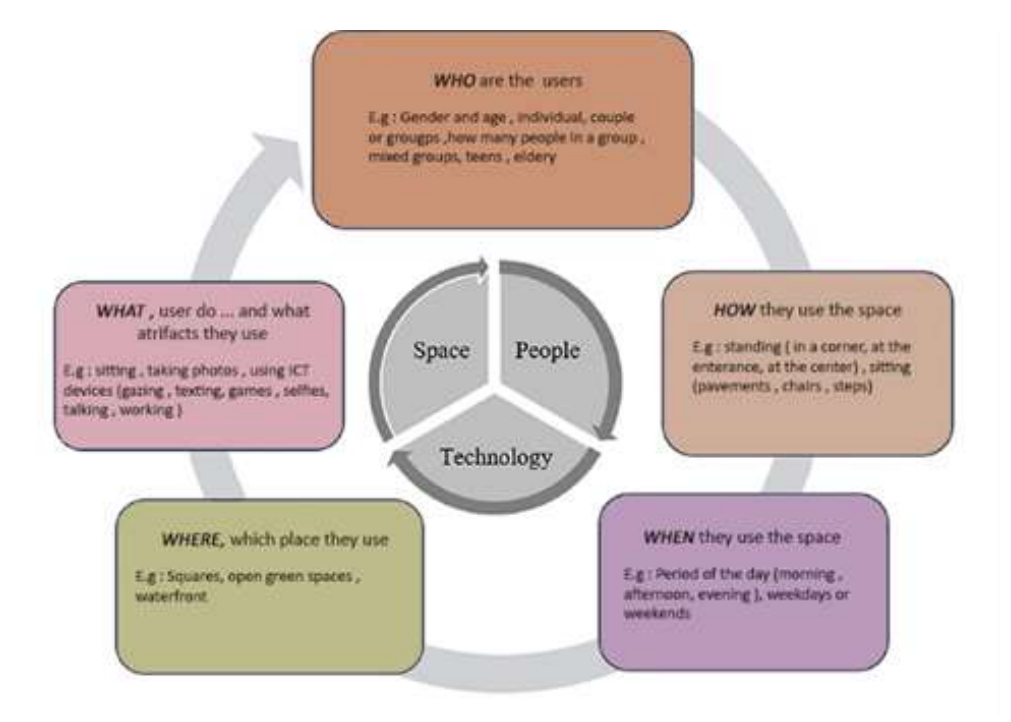

Fig. 2: 5 link point of ethnographic analysis approach: capturing the relationship between people, space \& technology: Source: Smaniotto Costa et al. ( 2019)

The study consists of several limitations. Due to time limitations, the mapping days were limited to two days of the week at each site. Children were excluded from the study as the probability of owning a portable ITC device was low. The study did not focus on the demographic factors such as cultural background, ethnicity, economic factors that affect social behaviour.

Selection of case studies was done based on, availability of physical elements and functional characteristics discussed in the theoretical framework. The selected public spaces were Independence Square, Arcade Independence square and the Floating Market. These public spaces are redevelopments or design projects, initiated, owned \& managed by the Urban Development Authority situated within the Colombo city limits.

\section{Findings and Analysis}

\section{ICT Based Activites and Functional Characteristics of the Public Space}

Through the analysis of data it could be identified that Floating Market is mostly used for waiting purposes between destinations, thus it functions as a transitional public space. In contrast, the Independence memorial square can be identified as a popular destination for leisure, fitness and sightseeing among its users. 
Table 3: Relationship between Users, Spatial Usage and Portable ICT Based Activities[RD1]

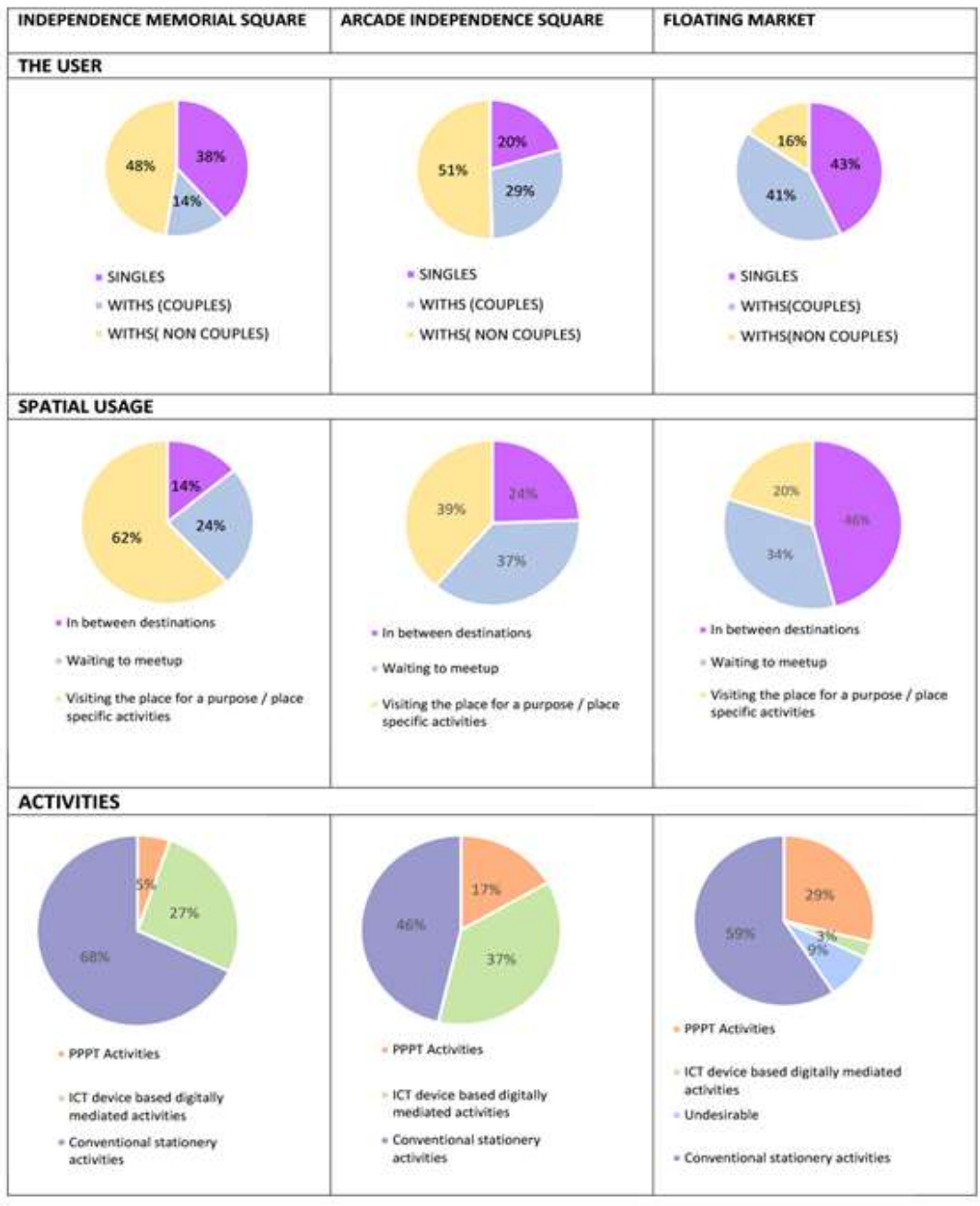

As evident above, the data showed a significant variation in PPPT based activities at Floating market and Independence square. Floating Market showed a higher frequency of these activities in comparison to the other selected public spaces. This variation of results can best be explained in relation to the user's purpose of visit to the place.

People visit Independence square for specific fitness related activities and sightseeing. People were observed being actively engaging in optional activities. Even though the variety of seating spaces in the outdoor areas were limited, people were still observed actively engaging in public activities. Majority of these observed users were in groups. Even the 'Singles' visiting the square were mostly observed being engaged in conventional activities such as sitting, standing, watching ,talking. They were rarely observed as engaged in PPPT bases activities. 


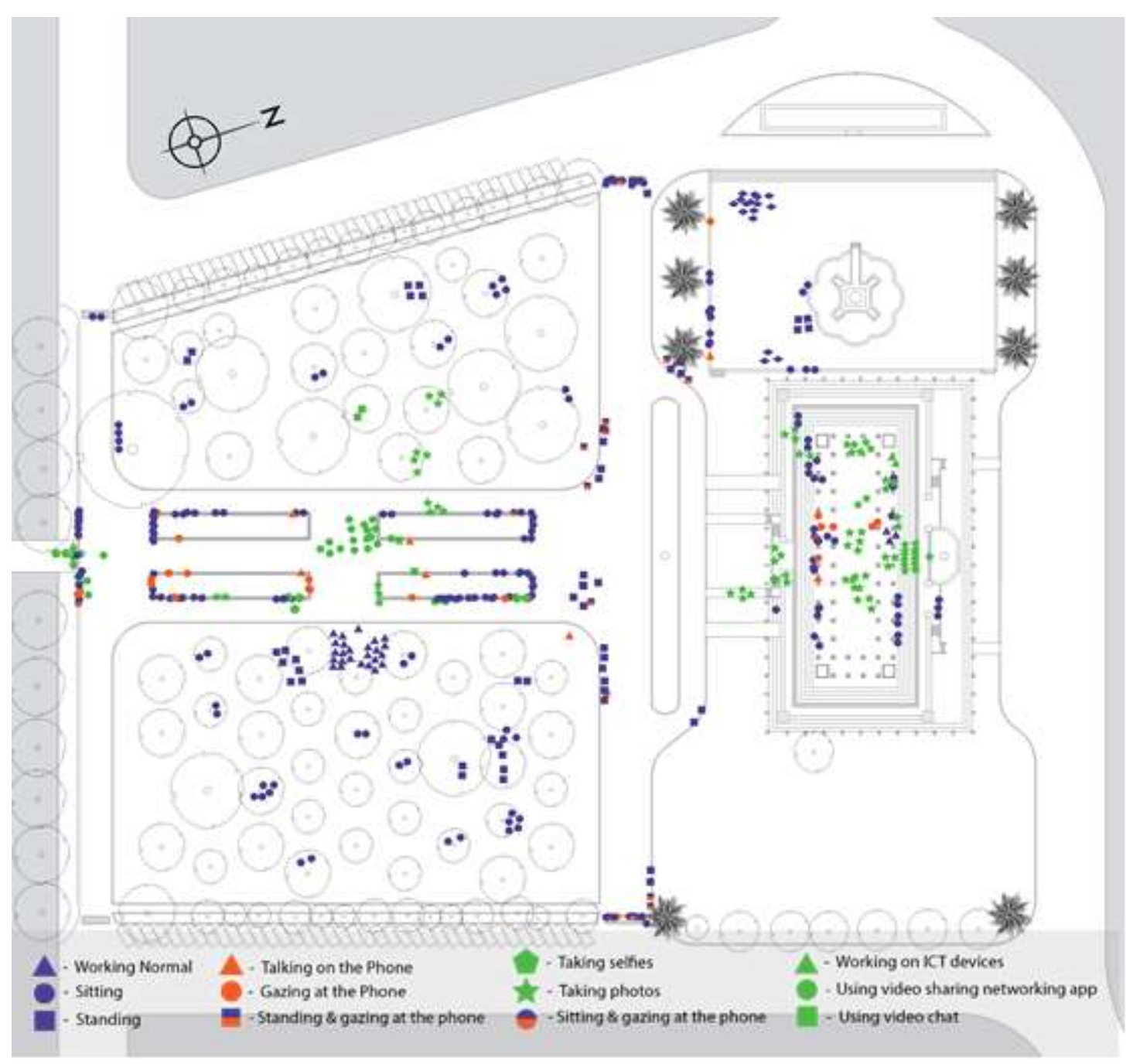

Fig. 3: Behaviour map of accumulated observations - Independence Square Source: author 


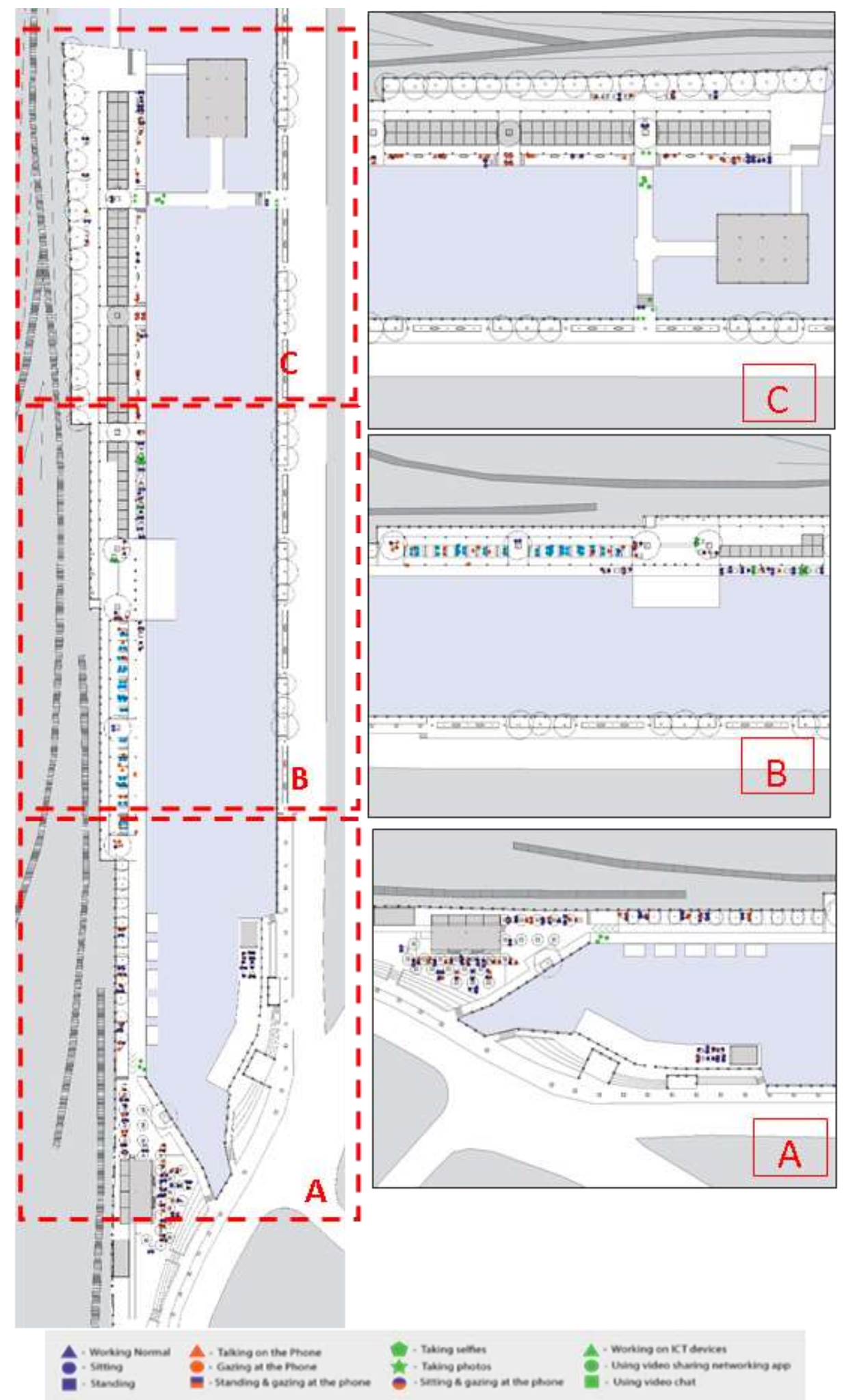

Fig. 4: Behaviour map of accumulated observations -Floating Market Source: author 
In contrast, Floating market was frequently observed being used by 'Singles' for waiting purposes while being engaged in PPPT based activities. Floating market consists of variety of seating and natural elements that provide comfortable micro climate. However it was observed that the quality of the built environment showed little relevance with the PPPT based activities observed at Floating Market. As it functions mostly as transitional public space, the location and the alleged illicit activities could also be strongly attributed for these behaviour patterns.

Digitally mediated activities were significantly observed at Arcade Independence and Independence square. Here the ICT devices were seen to be used as an interface to the conventional optional activities, thus mediating the social interactions and socio- spatial practices. Majority of the observed users were 'Withs' (non-couples) at these public spaces while Floating Market had a considerable low frequency of these types of activities and users.

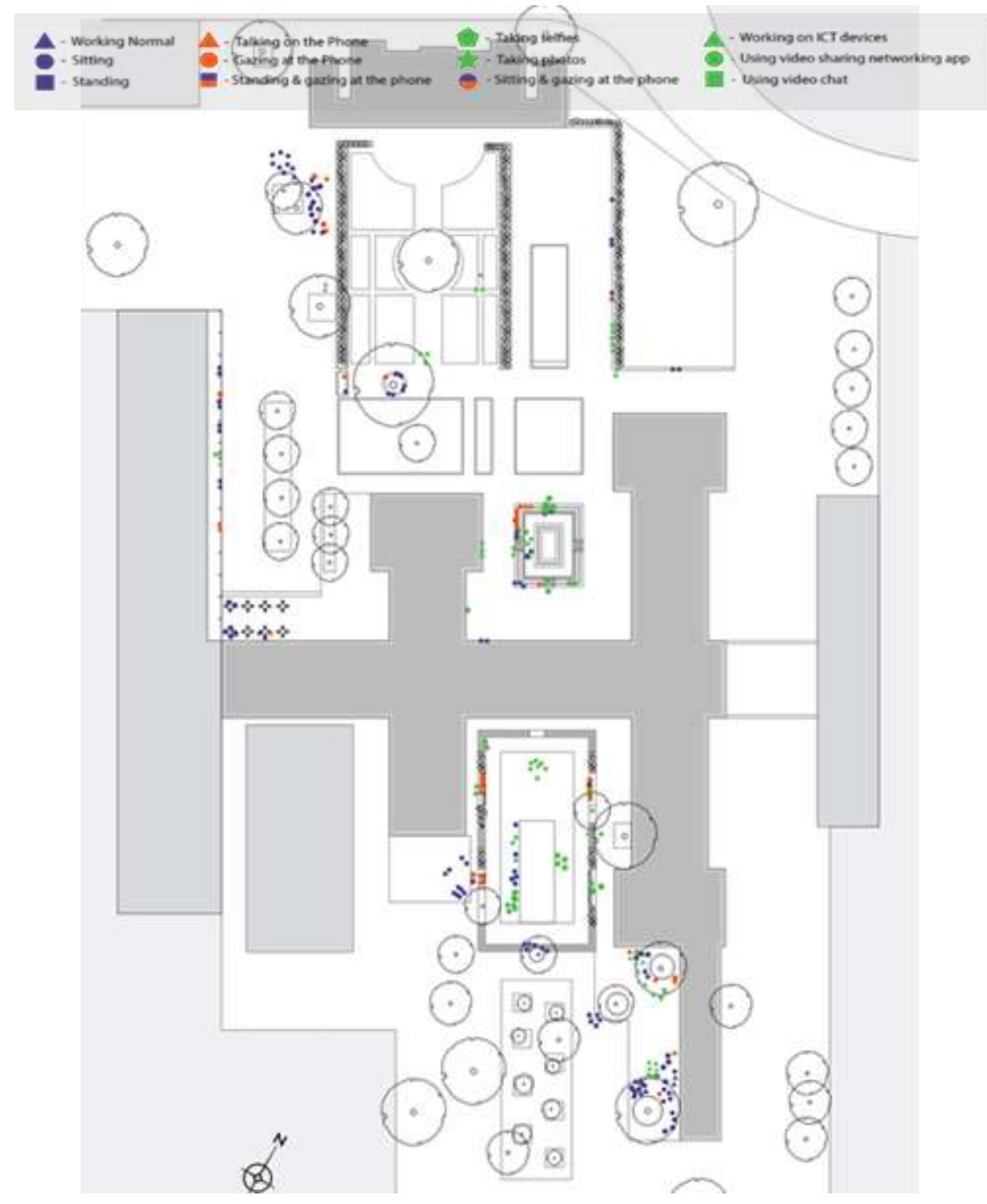

Fig. 5: Behaviour map of accumulated observations - Arcade Independence Square Source: author 


\section{ICT Based Activity Pattern in Different User Groups}

It is evident that majority of 'Singles' engage in PPPT activities. They were observed being detached from the physical surrounding. In addition, digitally mediated activities were frequently observed among 'Withs' who are non-couples. Couples mostly engaged in conventional activities, very few instances were observed where couples engaged in ICT based activities.

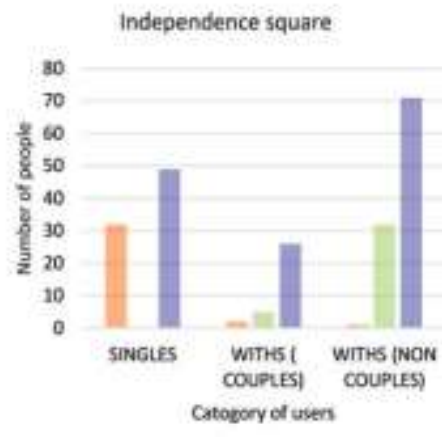

s PPPT Activities

sict devise based digitally medisted activities = Conventional stationery activities
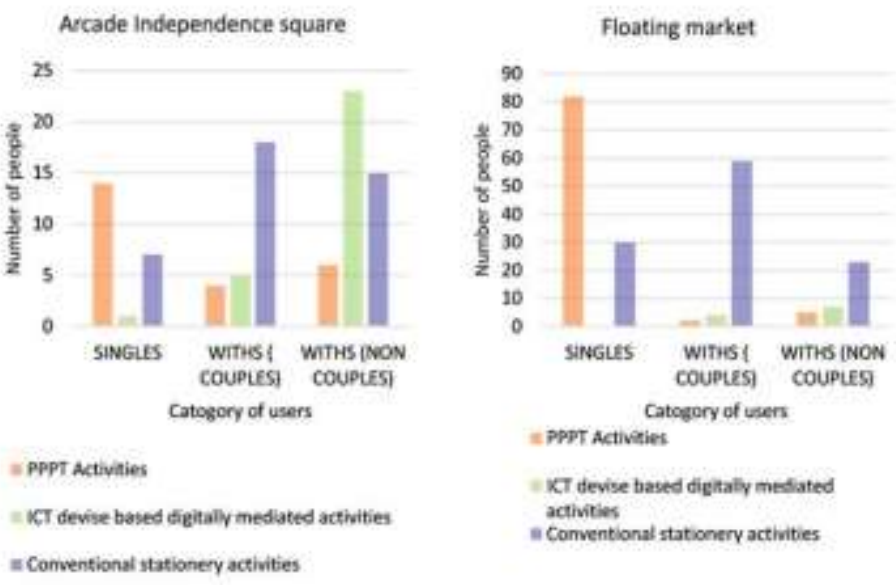

Fig. 6: Categories of activities in relation to user groups Source: Author

\section{Activity Patterns and Age Group}

ICT device based activities were mostly observed in users between the ages of $20-30$ years. People between the ages of $40-50$ were observed engaging in PPPT based activities in some urban spaces and yet were predominantly doing work based communication than socializing through ICT devices.
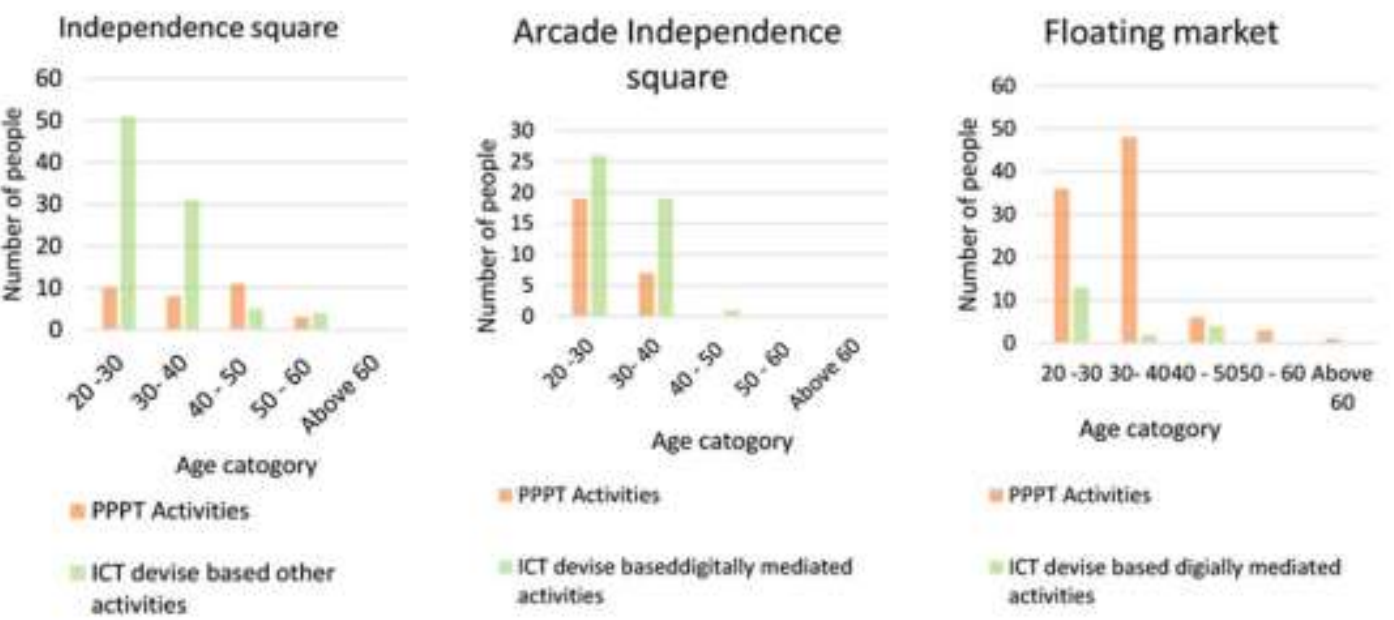

Fig. 7: ICT based activities and user groups Source: author 


\section{ICT Based Activity Patterns and Physical Environment}

Whyte (1980) perceives that individual fixed benches rarely encourage social interacts yet facilitate passive engagements among 'Singles'. In this study too it is evident majority of 'Singles' occupy individual fixed benches, in addition immerse in PPPTs regardless of its placement. These activities were mostly observed at Floating market and Arcade Independence square. Each fixed and bench units were occupied by individuals discouraging strangers to share. This, as a result, created a physical distance between users.

Similarly ledges placed away from the active area were observed occupied frequently by 'Singles' engaging in PPPT activities. Despite the location and orientation, these activities were observed near columns at Independence square and Arcade Independence square.
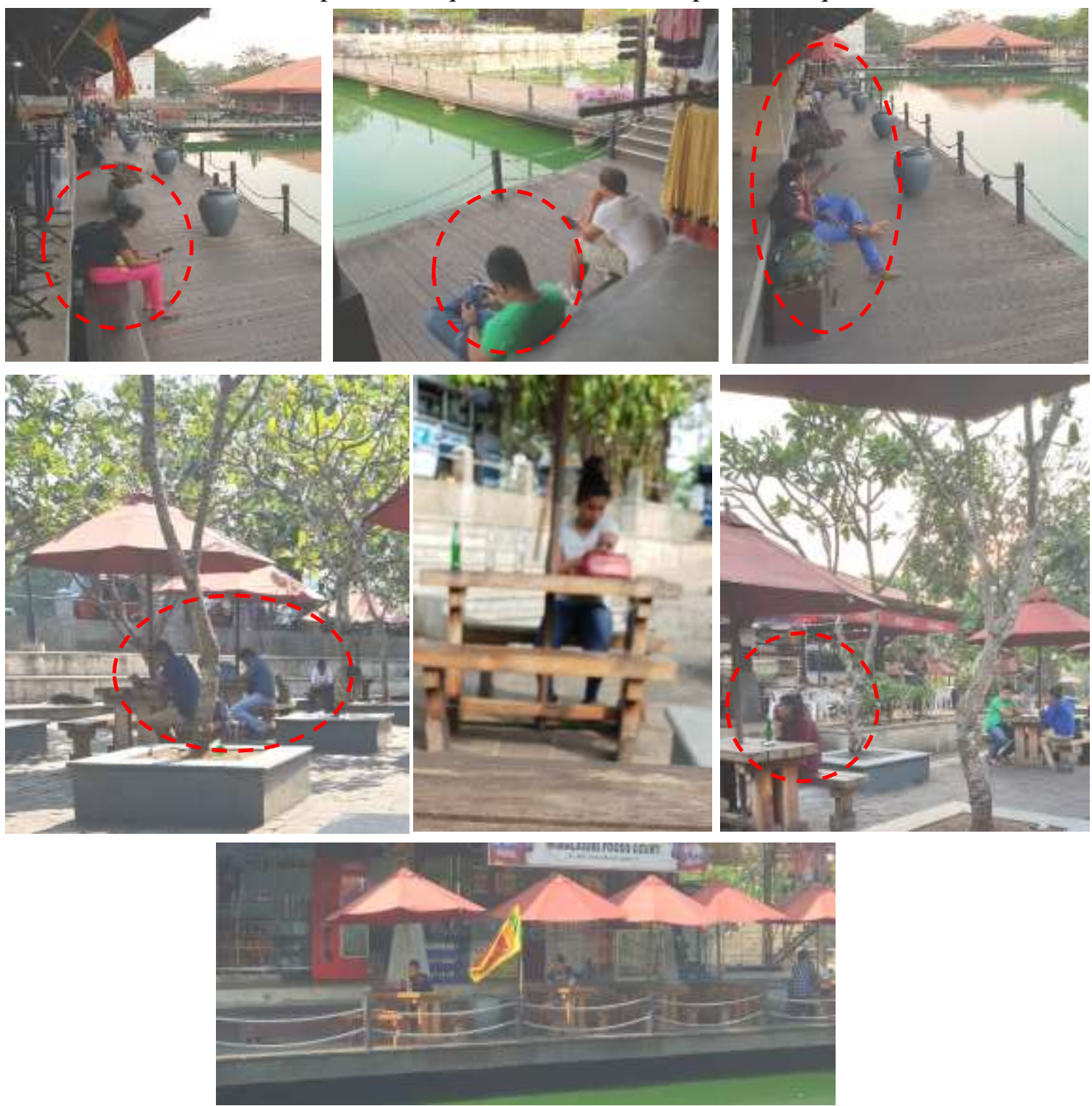

Fig. 8: PPPT activities at Floating Market - Fixed benches \& bench units Source: author 

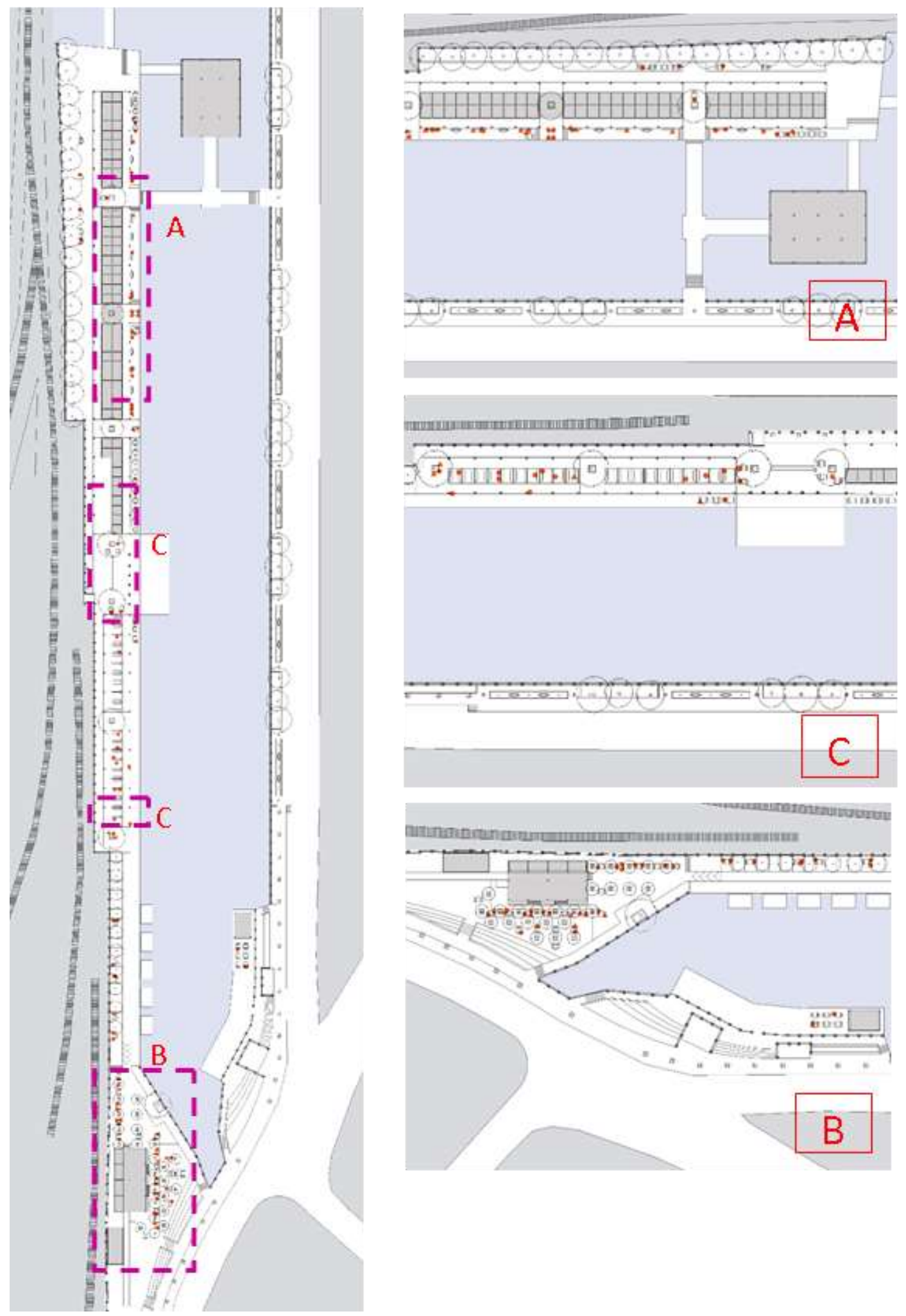

Fig. 9: Behaviour map of PPPT activities at Floating Market Source: Author 


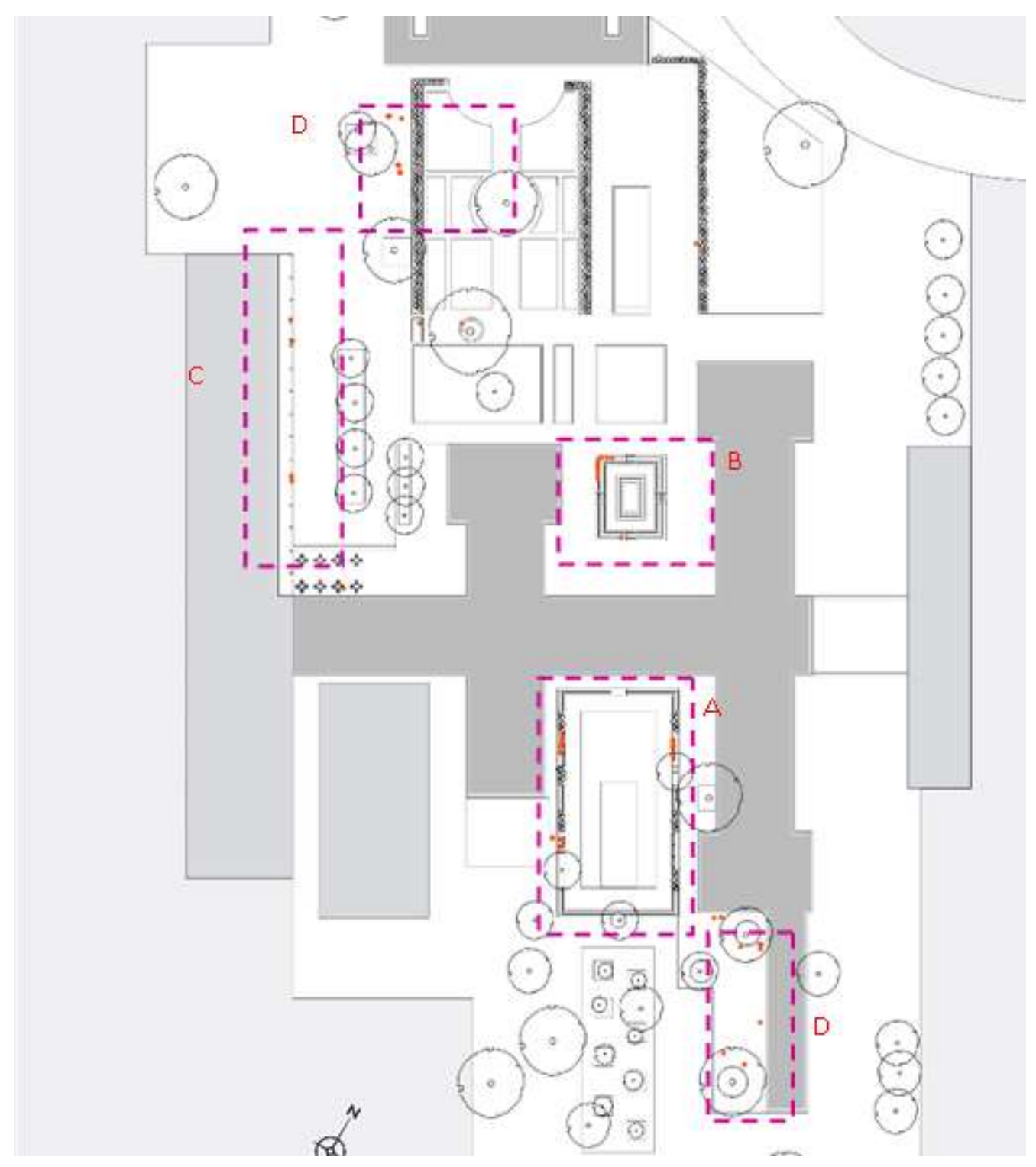

Fig. 10: Behaviour map of PPPT activities at Arcade Independence Source: Author
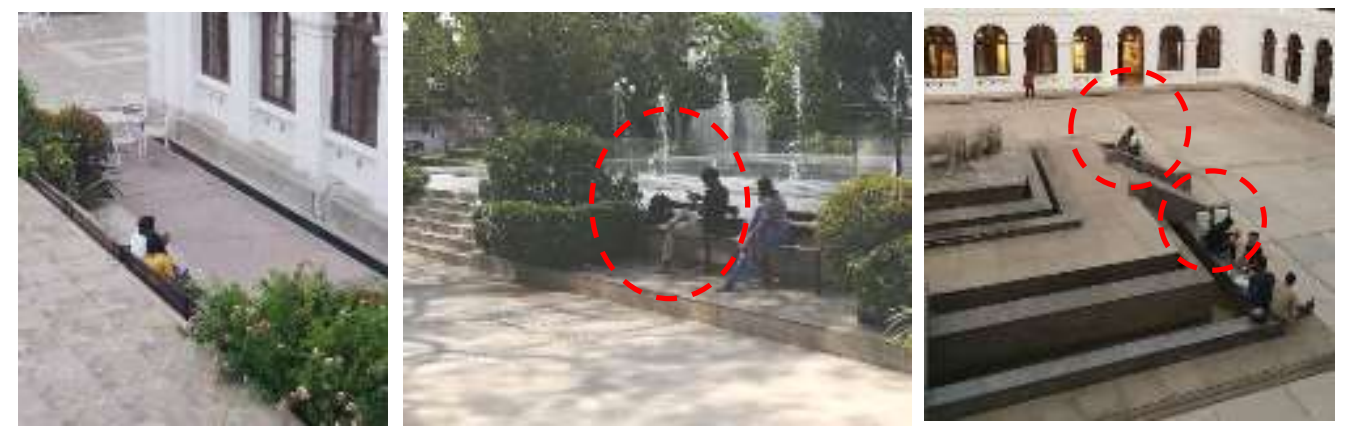

Figure 11: PPPT activities at Arcade Independence square - fixed benches \& ledges Source: author 

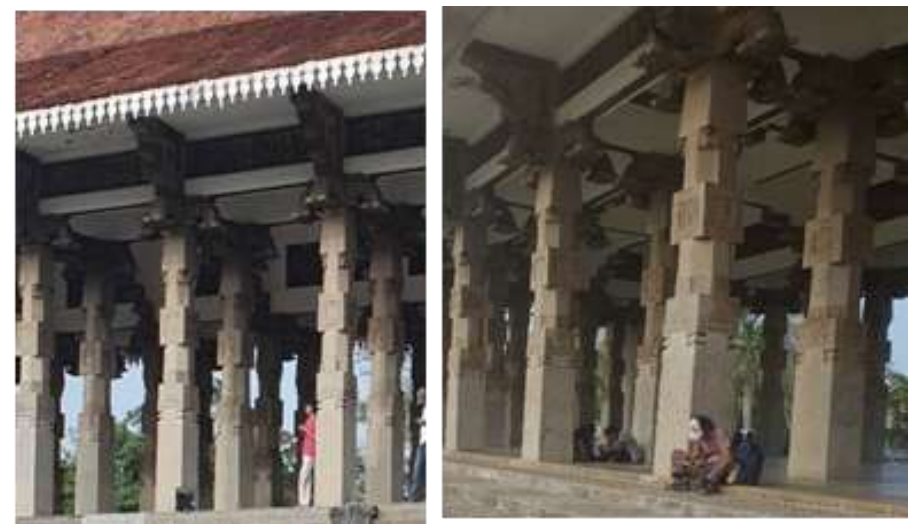

Fig. 12: PPPT activities near columns at Independence square - columns Source: Author

Water features and sculptures encourage people to interact with companions and strangers (Whyte, 1980) in outdoor public spaces. This scenario was observed at Independence square and Arcade independence. However it was intervened by the uses portable ICT and the experience was observed being altered by a digital interface. Sassen( 2015 ) states this as mediation of outdoor activities. On the contrary to social distancing norms, these encouraged people to gather. However, these activities were not prominent at Floating market.

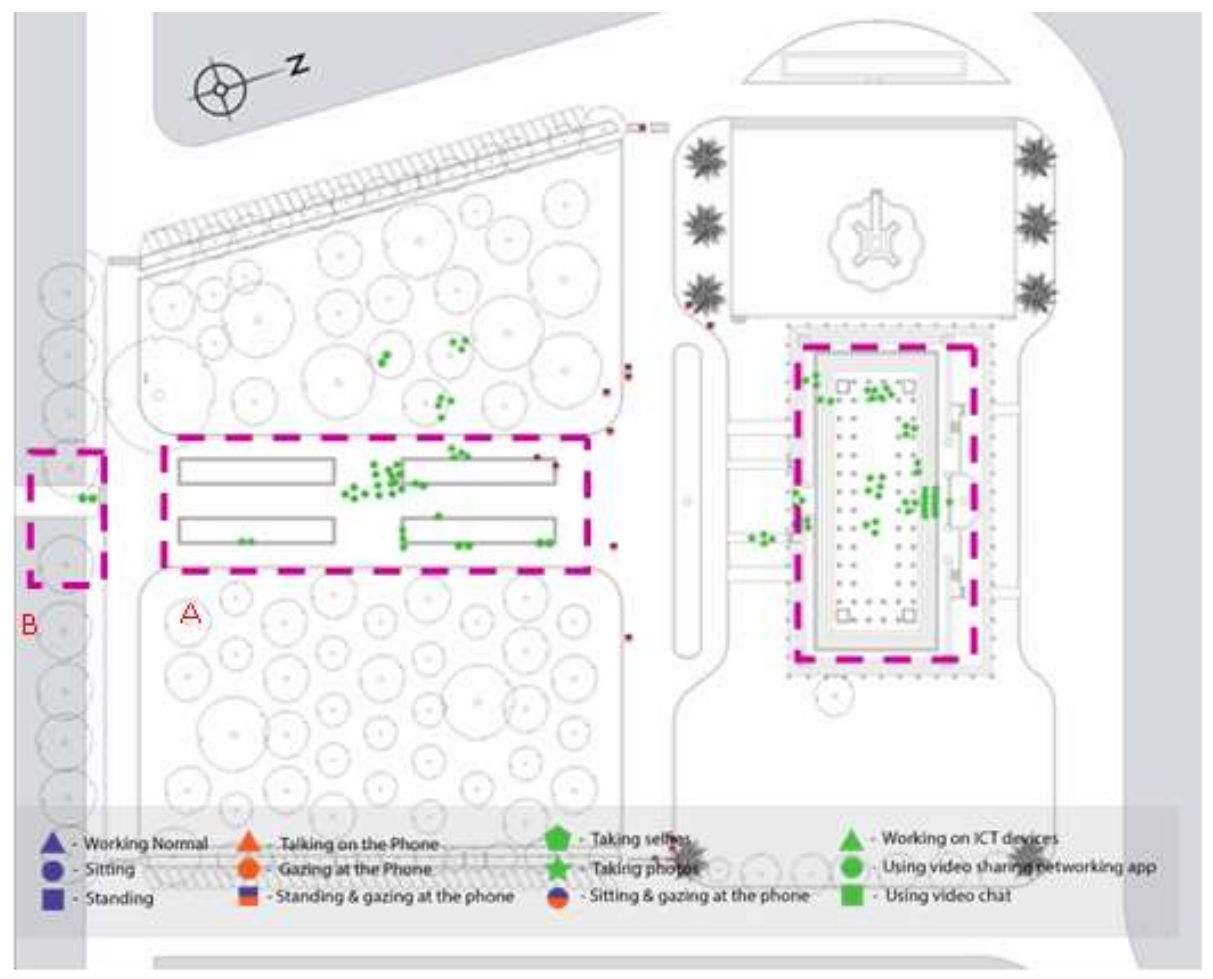

Fig. 13: Digitally modified activities at Independence square Source: Author 

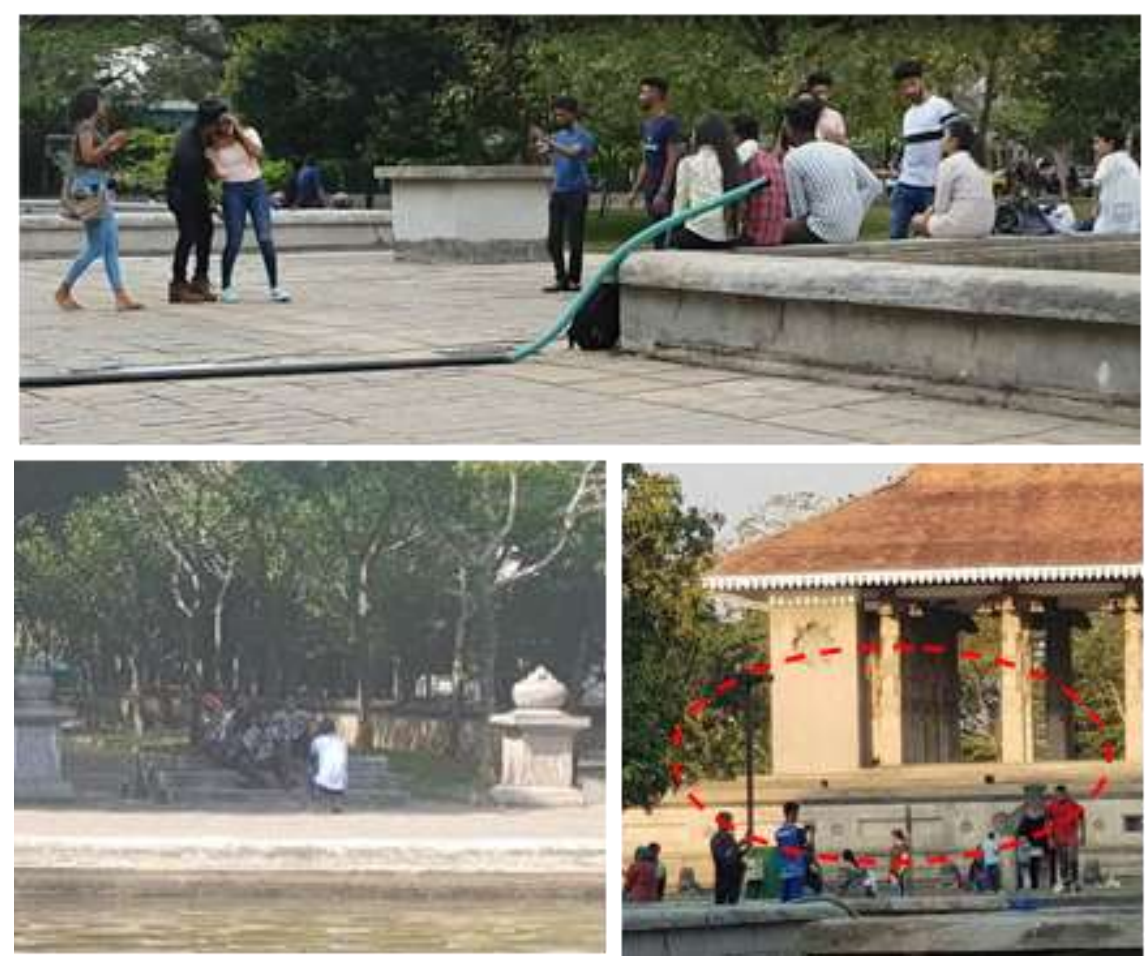

Fig. 14: Digitally modified activities (Tick tok) at Independence square Source: author
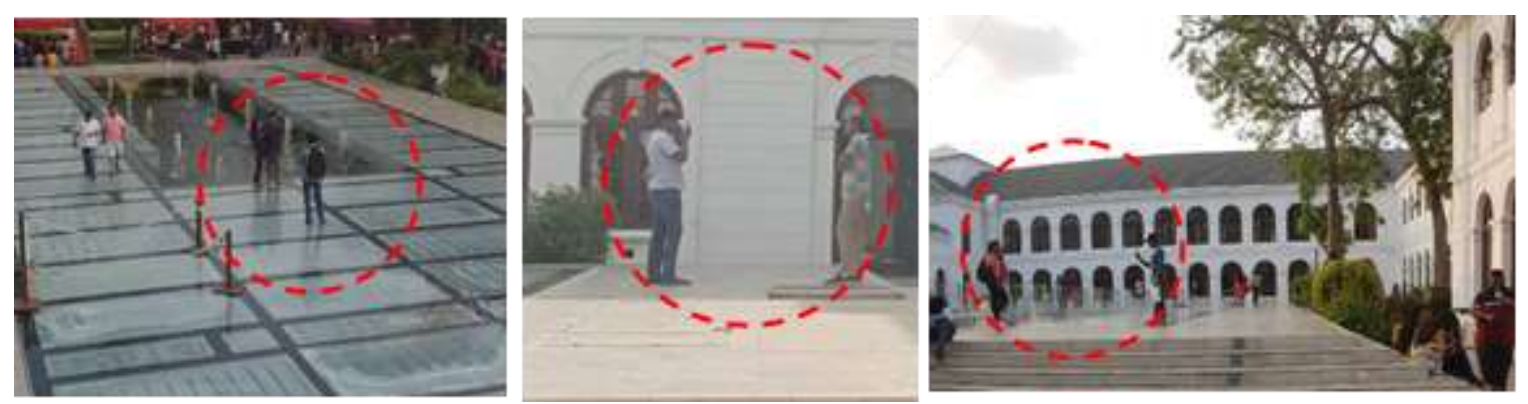

Fig. 15 : Digitally modified activities at Arcade Independence square Source: Author 

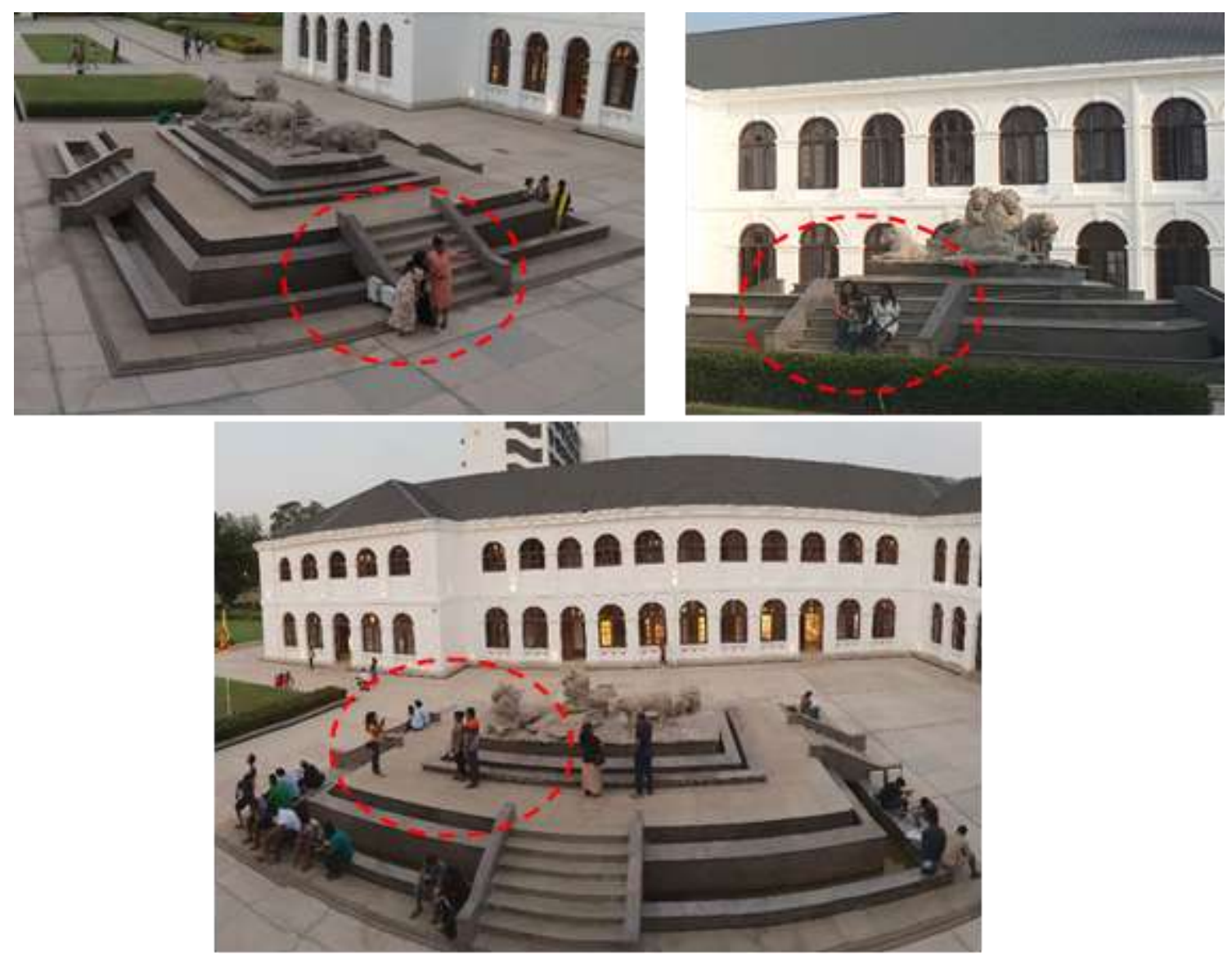

Fig. 16: Digitally modified activities at Arcade Independence square Source: Author

Arcade Independence square - triangulation being mediated by portable ICT devices Source: author

Table 4: Summery of the relationship between ICT Based Activity Patterns and Physical Environment

\begin{tabular}{|l|l|l|l|}
\hline \multirow{2}{*}{ ACTIVITY } & $\begin{array}{l}\text { INDEPENDENCE } \\
\text { MEMORIAL SQUARE }\end{array}$ & $\begin{array}{l}\text { ARCADE } \\
\text { INDEPENDENCE } \\
\text { SQUARE }\end{array}$ & FLOATING MARKET \\
\cline { 2 - 4 } & Physical / Design Elements & $\begin{array}{l}\text { Long Fixed benches } \\
\text { Bench units } \\
\text { Ledges around trees }\end{array}$ \\
\hline $\begin{array}{l}\text { PPPT } \\
\text { based } \\
\text { activities }\end{array}$ & $\begin{array}{l}\text { Ledges } \\
\text { Columns }\end{array}$ & $\begin{array}{l}\text { Fixed benches } \\
\text { Ledges } \\
\text { Columns }\end{array}$ & Water features \\
\hline $\begin{array}{l}\text { Digitally } \\
\text { modified } \\
\text { activities }\end{array}$ & Wedges & $\begin{array}{l}\text { Water features } \\
\text { Sculptures } \\
\text { Chairs with tables }\end{array}$ & \\
\hline
\end{tabular}




\section{Modifications in Socio - Spatial Practices}

With respect to all selected cases, the socio spatial practices were markedly modified by the users. Summary of which could be tabled as follows:

Table 5: Summery of Modification in Socio - Spatial Practices

\begin{tabular}{|c|c|c|}
\hline $\begin{array}{l}\text { ICT } \\
\text { Based } \\
\text { Activities }\end{array}$ & $\begin{array}{l}\text { Socio - } \\
\text { Spatial } \\
\text { Practices }\end{array}$ & Modification \\
\hline $\begin{array}{l}\text { PPPT } \\
\text { based } \\
\text { activities }\end{array}$ & Niche Effect & $\begin{array}{l}\text { These socio - spatial practices are mostly related with creating intimate } \\
\text { and personal spaces in public spaces. These encourage passive } \\
\text { engagements with the physical environment. 'Singles' are frequently } \\
\text { observed engaging in these socio - spatial practices. } \\
\text { These behavioural practices are now linked with people creating PPPTs } \\
\text { and temporarily detaching from the physical setting, sometimes to } \\
\text { engage in virtual publics. }\end{array}$ \\
\hline $\begin{array}{l}\text { Digitally } \\
\text { modified } \\
\text { activities }\end{array}$ & $\begin{array}{l}\text { Water effect } \\
\text { Triangulation } \\
\text { Tree effect }\end{array}$ & $\begin{array}{l}\text { These encourage active engagement in public spaces and encourage } \\
\text { social interaction among strangers. } \\
\text { Today, these socio - spatial practices happen through the portable ICT } \\
\text { devices and the device acts as an interface to the physical interactions. } \\
\text { Now triangulation is not limited physical location. Instead links the } \\
\text { physical space, person present in that space with the vast virtual } \\
\text { community. }\end{array}$ \\
\hline
\end{tabular}

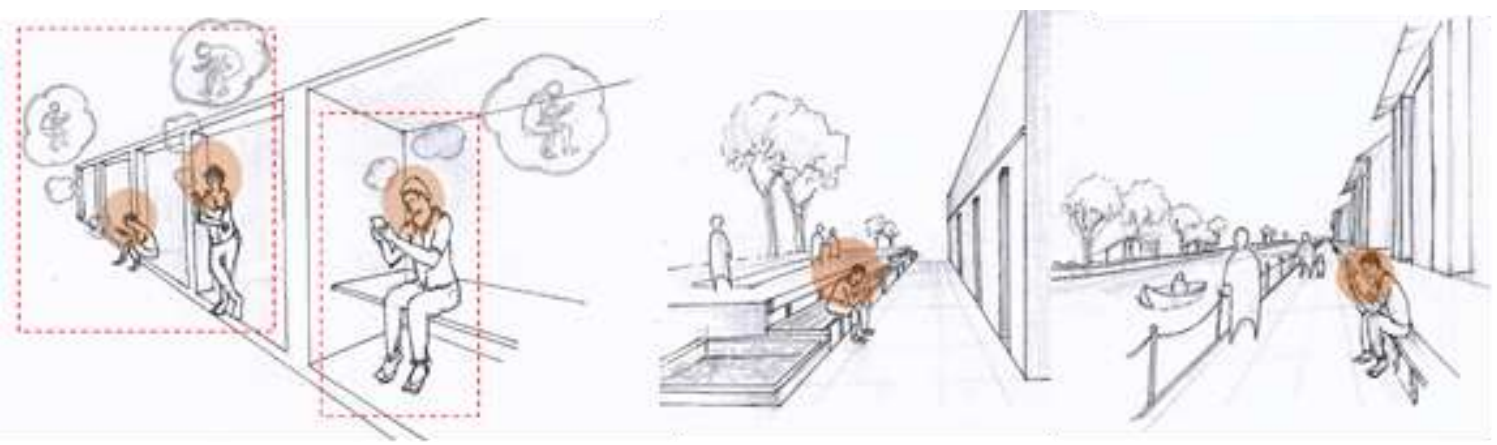

Fig. 17: Representation of modification of socio spatial practices due to PPPT activities Source: Author 

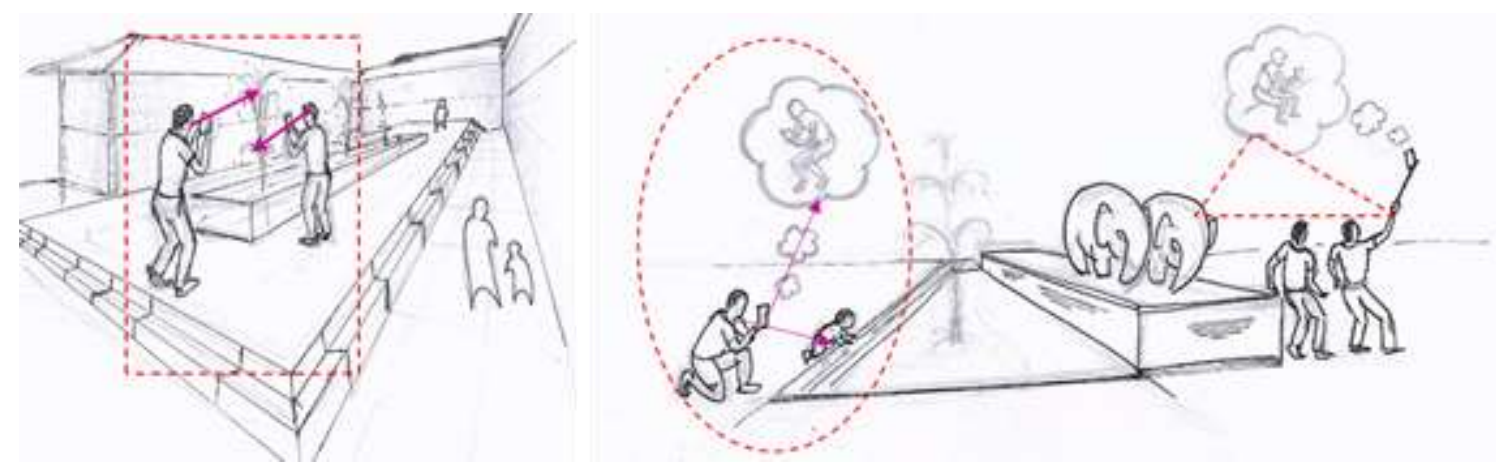

Fig. 18: Representation of modification of socio spatial practices due digitally modified activities Source: Author
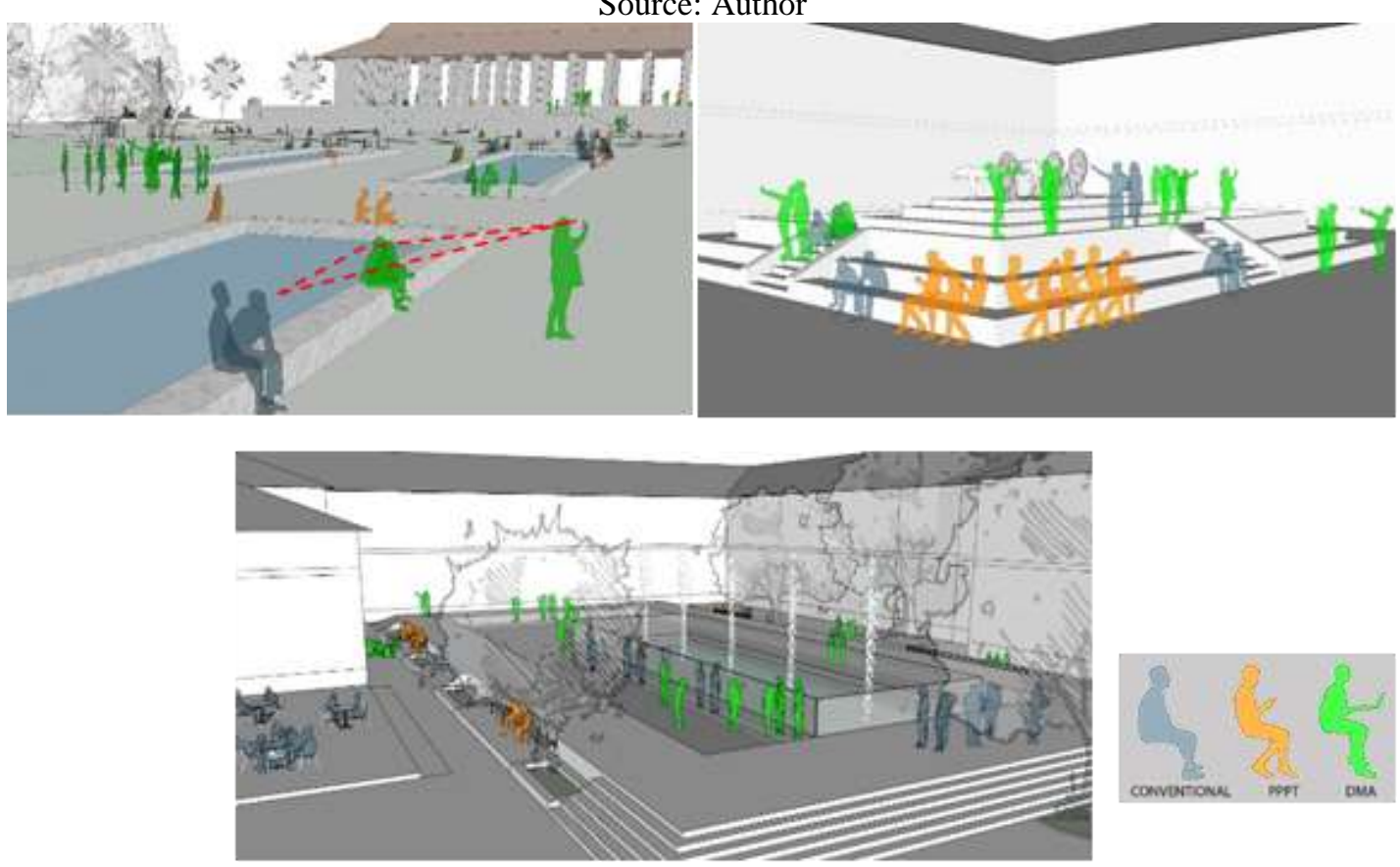

Figure 19: Representation of triangulation \& water effect modified due ICT device use Source: Author

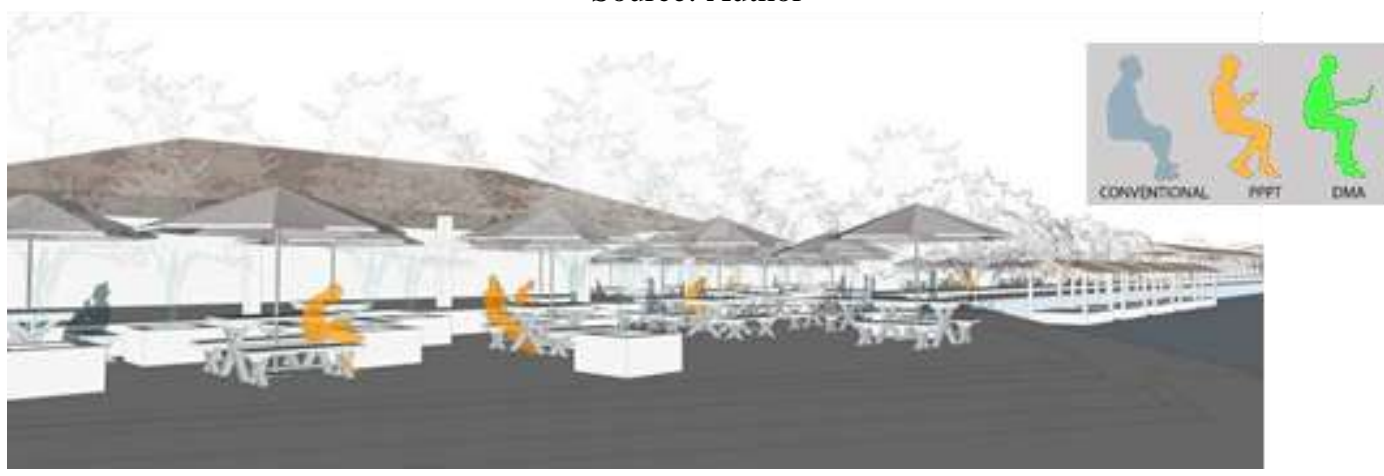

Fig. 20: Representation of tree effect modified due ICT device use Source: author 


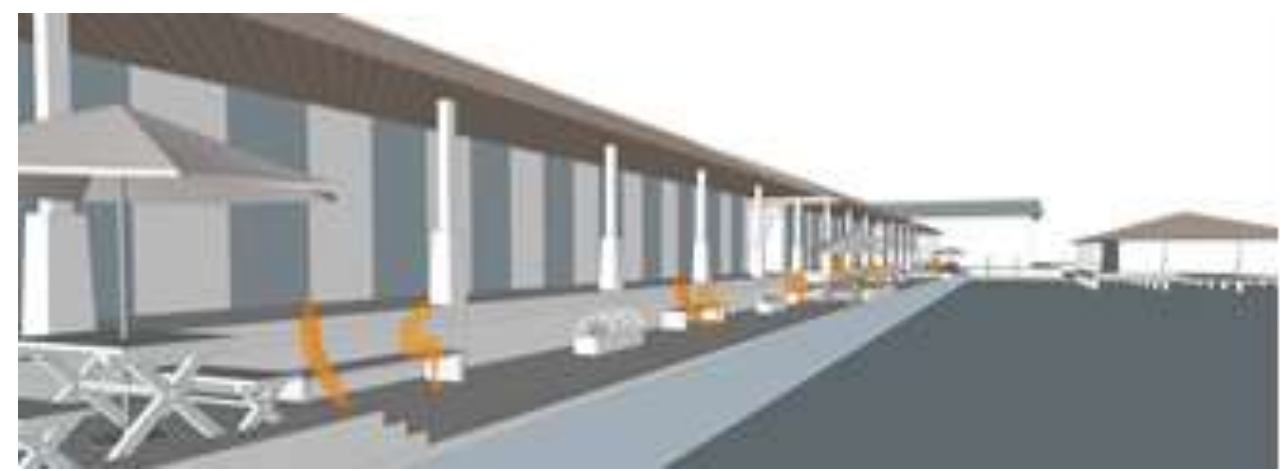

Fig. 21: Representation of piano effect $\&$ tree effect modified due ICT device use Source: Author

\section{Conclusion}

In this era of digitalization, the common conception is that ubiquitous computing and social network interactions have become a significant characteristic in urban lifestyle. Many ongoing global discussions suggest that public spaces and social interactions are being gradually intervened by a digital layer allowing people to integrate with digital and physical environments simultaneously.

It is evident in this research that outdoor public spaces in Colombo still remain as places of gathering and relaxation. However, a considerable number of people were also observed using portable ICT devices at these public spaces. A careful analysis of the user activities in these spaces suggests that ICT devices have penetrated into human urban outdoor life modifying both the spatial usage and conventional social activities.

The research identifies two major types of ICT device based activities in outdoor public spaces:

1. Activities that encourage formation of portable private - personal territories (PPPT) in public spaces; which includes activities such as gazing at the phone, conversing on the phone.

2. Digitally modified activities; which includes taking photos and selfies using smartphones, working on laptops, using video sharing social networking apps

The above suggests that new optional activities, in addition to the activities identified by Gehl (2011), are happening and are mediating the social activities in these outdoor public spaces. Hatuka (2016) identifies this phenomenon as a modification of social rituals in outdoor public spaces.

In the cases studied, the use of portable ICT devices can be seen strongly related to the context and user's purpose of visit to the public space. ICT device based activities vary depending on the functional characteristic of the outdoor public spaces. Users of Transitional public spaces exhibit higher frequency of PPPT based activities while the users in Destination type public spaces demonstrate least amount of PPPT based stationery activities. Public spaces which function as both transitional and destination types reveal a higher number of digitally modified activities. With respect to the cases studied, this findings explicate that the use of portable ICT devices predominantly depend on the functional characteristics of a public space than the physical quality of the outdoor public spaces in Colombo. In global research field similar conclusions have been made by Rasouli ( 2013), Hampton, Goulet and Albanesius (2015) who suggest context specific 
functions and appropriate categories of activities influence the use of portable ICT devices. This suggests that architects and urban planners having a prior and comprehensive understanding of the function and relationship of an urban public context is important in determining the level of digital interface when designing urban public spaces.

Additionally, majority of the observed ICT device users were between the age of $20-30$. Which forecasts a possibility of higher ICT device users in the future, indicating that the interference of digital layers in outdoor public spaces cannot be completely disregarded.

Sculptures and water features were identified as elements that stimulate active engagement in public space. Today through portable ICT devices such elements stimulate active social interactions in both physical and virtual public spaces simultaneously. These physical settings allow people to engage in multiple spheres through a digital interface i.e. Smartphones.

The findings further reveal that formation of PPPTs were mostly observed in relation to individual fixed elements in public spaces. These physical elements were mostly occupied by 'singles' indicating that individual people use these types of physical settings to create a personnel space within a public space. According to Whyte (1980) individual elements rarely encourage social interactions among groups but facilitate passive engagements among individuals. Today due to the formation of PPPTs, such passive engagement in outdoor public spaces are being reduced.

When it comes to pandemics such as Covid -19 , social distancing particularly discourages the conventional social activities in urban public spaces. Therefore exploring future prospects of urban public spaces with social distance guidelines would be a new paradigm in urban design and planning sphere. The identified relationship between PPPTs and fixed element use in urban public spaces hints at fresh possibilities of maintaining physical distancing in public spaces by making allowances to PPPT facilitated virtual interactions in users. PPPTs and fixed individual built elements, which were considered until recent times as unsuccessful in stimulating social interactions, can now be positively incorporated in to public spaces permitting its users to interact in a virtual public spaces while still being present in the physical space. However this will not be fully pertinent for the people who visit the public spaces in groups.

Elements which encourage social interactions also provide the possibility of incorporating them into virtual sphere via ICT devices. This however presents the possibility of experiencing public spaces from a distant location minimizing the requirement of physically visiting the space. Nevertheless it alters the real-time physical experience. Further the simulative quality of these elements could make physical distancing practices unexciting.

In conclusion the research attempts to widen the thinking sphere of architects and urban planners towards new found definitions of urban public spaces with the interference of digital interfaces. In addition, it insinuates architects and urban planners to reshape urban public spaces that would be socially inclusive and functional even in a time of physical distancing period with the integration of virtual connectivity.

\section{References}

Abdel-Aziz, A. A., Abdel-Salam \& H. \& El-Sayad, Z. (2016) 'The role of ICTs in creating the new social public place of the digital era', Alexandria Engineering Journal, Vol 55, no.1, p.p $487-493$

Almatarneh, R. (2014) 'Analysis of Activity Patterns and Design Features Relationships in Urban Public Spaces: A Case Study of the Old City of As-Salt', International Journal of Computational Engineering Research, Vol 4, no.2, p .p $34-50$

Carmona, M., Tiesdell, S., Heath, T. \& Oc, T. (2010) Public places - urban spaces: the dimension of urban design, $2^{\text {nd }}$ edn, Boston: Elsevie 
Cooper,M.C.\& Carolyn Francis, C. (1997) People Places: Design Guidelines for Urban Open Space, 2nd edn. New York: Van Nostrand Reinhold.

Duffey, M. (2014) 'Hybrid Spaces : Users 'Perceptions of Digitally Mediated Public Space', All Dissertations, Clemson University

Fritz, J. (2013) 'Book Review: Gener al Politics: The Routledge Handbook of Internet Politics', Political Studies Review, Vol. 11 , no. 2, p.p 268-268

Gehl, J., (2010) Cities for people. $1^{\text {st }}$ edn, Washington, D.C.: Island Press

Gehl, J. (2011) Life between Buildings: Using Public Space, Landscape Journal, Washington: Island press.

Gehl, J. \&Svarre, B., (2013) How to Study Public Life, $1^{\text {st }}$ edn, Washington, D.C.: Island Press

Ghoneim E. M. \& Megahed N. A. (2020) Antivirus-built environment: Lessons learned from Covid-19 pandemic, Sustainable Cities and Society, Vol 61.

Goffman E (1963) Behaviour in Public Spaces, New York: The Free Press.

Goffman E (1971) Relations in Public. New York: Basic Books

Hampton, K. N., Livio,O. \& Goulet, L.S. (2010) 'The social life of wireless Urban spaces', Social Networks, and the Public Realm, Journal of Communication, Vol 60, no.4, p.p $701-722$

Hampton, K. N., Goulet, L. S. \& Albanesius, G. (2015) 'Change in the social life of urban public spaces: The rise of mobile phones and women, and the decline of aloneness over 30 years', Urban Studies, Vol. 52, no.8 p.p 1489-1504

Hatuka, T. \& Toch, E. (2016) 'The emergence of portable private-personal territory: Smartphones, social conduct and public spaces', Urban Studies, Vol 53, no.10, p.p 1- 7

Howell, P., (1993) Public Space and the Public Sphere: Political Theory and the Historical Geography of Modernity, Environment and Planning D Society and Space, Vol 11, no.3, p.p 303-322

Humphreys, L. (2005) 'Cellphones in public: Social interactions in a wireless era', New Media and Society, Vol. 7, no.6, p.p 810-833

Johansson, E. \& Emmanuel, R. (2006) ' The influence of urban design on outdoor thermal comfort in the hot, humid city of Colombo, Sri Lank', International Journal of Biometeorology, Vol. 51, no.2, pp. 119 - 133

Samuelsson, K., Barthel,S., Colding, J., Macassa,G. \& Giusti, M.(2020), 'Urban nature as a source of resilience during social distancing amidst the coronavirus pandemic', BIG project: Spatial and Experiential Analyzes for Urban Social Sustainability, viewed 28 September, ResearchGate

Turkle, S. (2011), Alone together: why we expect more from technology and less from each other , New York : Basic Books

Lehel, S. R. (2016) 'The decline of virtual reality and the rise -a digital reshape of public spaces, Journal of Urban and Landscape Planning, Vol. 1, pp. 12-21.

Lofland, L. (1973) A World of Strangers: Order And Action in Urban Public Space. New York: Basic

Maksymiuk, G., Suchocka, M., Kimic,K. \& Kołodyńska, N. (2017) 'Behaviour, expectations and preferences of "digital natives" in regard to the design of urban public spaces', in Enhancing places through technology, Proceedings of the ICiTy conference Valletta: Malta ,April 18-19, 2016, pp.117-128.,

Menezes, M. \& Smaniotto Costa, C. (2017) 'People, public space, digital technology and social practice: an ethnographic approach', in Enhancing Places through Technology, $1^{\text {st }}$ edn, Switzerland, Springer, pp. 167-180

Nguyen, C. T. et al. (2020) 'A Comprehensive Survey of Enabling and Emerging Technologies for Social Distancing - Part I: Fundamentals and Enabling Technologies', IEEE Access, Vol.4, p.p 1- 28 
Rasouli, M. (2013) 'Analysis of Activity Patterns and Design Features Relationships in Urban Public Spaces Using Direct Field Observations, Activity Maps and GIS Analysis Mel Lastman Square in Toronto as a Case Study', UWSpace.

Sassen, S. (2015) Citizen's Right to the Digital City: Urban Interfaces, Activism, and Place making, $1^{\text {st }}$ edn, Singapore: Springer

Smaniotto Costa, C. (2019) CyberParks - The Interface Between People, Places and Technology, $1^{\text {st }}$ edn, Switzerland : Springer

Stadler, R. L. (2013) 'ICTs as a tool to increase the attractiveness of public spaces', Science future of Lithuania, Vol. 5, no.3, p.p 216-228

Sennett R (1977) The Fall of Public Man, New York: Knopf.

Whyte, W. H. (1980), The social life of small urban spaces, Washington, D.C.: The Conservation Foundation

\author{
Abbreviation \\ ICT - Information \& Communication Technologies \\ UDA - Urban Development Authority \\ PPPT - Portable Private - Personal Territories
}

